\title{
Adult learning and education as a tool to contain pandemics: The COVID-19 experience
}

\author{
Henrique Lopes $^{1}$ (D) . Veronica McKay ${ }^{2}$ (D)
}

Published online: 18 June 2020

(c) UNESCO Institute for Lifelong Learning and Springer Nature B.V. 2020

\begin{abstract}
In combating pandemics, more can be gained by changing citizens' behaviours than by relying solely on the medical route. In the current COVID-19 pandemic, the struggle to contain the outbreak and push back new infection figures will ultimately be won by training citizens how to avoid creating secondary transmission chains. The COVID-19 pandemic highlights the relationship between individual behaviour and group risk. Mass training of all social strata of a country's entire population is therefore critical in mitigating the pandemic. The authors of this article argue that adult learning and education (ALE) can play a pivotal role particularly in countries where average literacy levels are low, as these are usually the same countries in which healthcare systems are more fragile. This article explains why ALE, especially the promotion of health literacy as part of ALE (which is itself part of lifelong learning), is necessary to enable individuals to make informed health-related decisions. Research has shown that low- or non-literate individuals are less responsive to health education, less likely to use disease prevention services, and less likely to successfully manage chronic disease than literate citizens. The authors refer to the evaluation of the health literacy aspect of a large-scale adult literacy campaign launched in South Africa in 2008 which has yielded measurable outcomes and proved that the intervention had enabled adults to better understand health messages. They stress the importance of populations having at least a basic level of literacy and numeracy skills to enable them to receive and act on vital information during a pandemic or disaster. They argue that ALE should in fact be understood as an inherent element of every national emergency strategy, both in terms of prior preparation for possible future emergencies (such as pandemics, earthquakes, tornados, flooding, bushfires etc.), and in terms of reaction to a given emergency such as the current COVID-19 pandemic.
\end{abstract}

Keywords adult education · COVID-19 $\cdot$ pandemics $\cdot$ health literacy $\cdot$ adult learning $\cdot$ advocacy $\cdot$ health campaigns

Veronica McKay

mckayvi@gmail.com

Extended author information available on the last page of the article 


\section{Résumé}

L'apprentissage et l'éducation des adultes, un outil pour endiguer les pandémies : l'expérience du COVID-19 - Dans la lutte contre les pandémies, on peut obtenir de meilleurs résultats en changeant les comportements des citoyens qu'en se fiant uniquement à la solution médicale. Dans le cas de la pandémie de COVID-19 qui nous préoccupe actuellement, nous gagnerons le combat mené pour contenir l'épidémie et réduire le nombre de nouvelles infections en apprenant aux citoyens comment éviter de créer des chaînes de contamination secondaire. La pandémie de COVID-19 met en relief la relation entre le comportement des individus et les risques pour le groupe. Pour la faire régresser, il est par conséquent crucial d'éduquer massivement toutes les couches sociales de la population d'un pays. Les auteurs de cet article affirment que l'apprentissage et l'éducation des adultes peuvent jouer un rôle déterminant dans les pays ayant un faible niveau d'alphabétisme, qui sont d'ordinaire également ceux où les systèmes de santé sont plus fragiles. Cet article explique pourquoi l'apprentissage et l'éducation des adultes, en particulier la promotion de l'alphabétisation sanitaire dans le cadre de l'apprentissage et de l'éducation des adultes, sont nécessaires pour permettre aux individus de prendre des décisions éclairées en matière de santé. Des recherches ont montré que les personnes illettrées ou analphabètes étaient moins ouvertes à l'éducation en matière de santé, qu'il était moins probable qu'elles s'adressent à des services de prévention des maladies et qu'elles avaient moins de chances de réussir à gérer des maladies chroniques que des citoyens instruits. Les auteurs renvoient à l'évaluation du volet d'alphabétisation sanitaire qui faisait partie d'une campagne d'éducation des adultes lancée à vaste échelle en Afrique du Sud en 2008. Il fournit des résultats quantifiables et prouva qu'il avait permis aux adultes de mieux comprendre les messages sanitaires. Les auteurs soulignent également l'importance pour les populations de posséder tout au moins des bases de lecture, d'écriture et de calcul pour pouvoir recevoir des informations vitales pendant une pandémie ou un cataclysme et être à même d'agir en fonction. Ils affirment qu'il conviendrait de considérer l'apprentissage et l'éducation des adultes comme faisant partie intégrante de toute stratégie d'urgence nationale, tant pour ce qui est de la préparation à d'éventuelles crises à venir (pandémies, tremblements de terre, tornades, inondations, feux de brousse, etc.) qu'en ce qui concerne la réponse à une situation d'urgence donnée comme c'est par exemple le cas de la pandémie de COVID-19.

\section{Resumen}

El aprendizaje y la educación de adultos como herramienta para contener las pandemias: la experiencia de COVID-19 - En la lucha contra las pandemias, el cambio del comportamiento de los ciudadanos podría ser más beneficioso que confiar únicamente en la vía médica. En la actual pandemia COVID-19, la lucha para contener el brote y hacer retroceder las nuevas cifras de infección se ganará en última instancia capacitando a los ciudadanos para evitar la creación de cadenas de transmisión secundarias. La pandemia COVID-19 pone de relieve la relación entre el comportamiento individual y grupal de riesgo. Como consecuencia, la capacitación masiva de todos los estratos sociales de toda la población de un país es fundamental para mitigar la pandemia. Los autores de este artículo sostienen que el aprendizaje y la educación 
de adultos (EAA) podrían desempeñar un papel fundamental, principalmente, en los países en los que los niveles medios de alfabetización sean bajos, ya que suelen ser los mismos países en los que los sistemas de salud son más frágiles. En este artículo se explica por qué el EAA, especialmente la promoción de la alfabetización en materia de salud como parte del EAA (que a su vez forma parte del aprendizaje a lo largo de toda la vida), es necesaria para que las personas puedan tomar decisiones informadas en materia de salud. Las investigaciones han demostrado que las personas con bajo nivel de alfabetización o analfabetas responden menos a la educación sanitaria, tienen menos probabilidades de utilizar los servicios de prevención de enfermedades y menos probabilidades de gestionar con éxito las enfermedades crónicas que los ciudadanos alfabetizados. Los autores señalan una evaluación sobre el valor de la alfabetización en materia de salud de una campaña de alfabetización de adultos a gran escala iniciada en Sudáfrica en 2008, que ha dado resultados válidos y ha demostrado que la intervención ha permitido a los adultos comprender mejor los mensajes sobre la salud. Además, subrayan la importancia de que las poblaciones tengan por lo menos un nivel básico de conocimientos de lectura, escritura y aritmética que les permita recibir información importante y actuar en consecuencia durante una pandemia o un desastre. Sostienen que el EAE debe entenderse, de hecho, como un elemento inherente a toda estrategia nacional de emergencia, tanto en lo que respecta a la preparación previa para posibles emergencias futuras (como pandemias, terremotos, tornados, inundaciones, incendios forestales, etc.), como en lo que respecta a la reacción a una emergencia determinada, como la actual pandemia COVID-19.

\section{Introduction}

The current coronavirus pandemic, COVID-19, draws attention to the urgent need for each citizen to be equipped to become a health security vector. ${ }^{1}$ According to the limited literature pertaining to the outbreak of the pandemic ( $\mathrm{Wu}$ and McGoogan 2020) and subsequent and ongoing research, for adults (Lopes and Middleton 2020; Lopes, Middleton et al. 2020a, Middleton et al. 2020) and children (Lopes, Middleton et al. 2020b) there is general agreement that people are particularly exposed to infection through close family or work contacts, as transmission seems to occur through contaminated droplets expelled by an infected person who is less than two metres away. Although recent literature highlights that the national ecosystem and the size of the transmission chain are also important (Anderson 2020), the mediating factor with COVID-19 appears to be physical distance, as those who are infected pose less risk to others if they are at least two metres away from them (Yee et al. 2020). This measure can be strongly reinforced by the use of masks.

The current pandemic has given rise to a number of behavioural patterns that are common to large-scale health threats (Jones 2020). One phenomenon is that the circulation of misinformation about COVID-19 (Depoux et al. 2020) has prompted

\footnotetext{
${ }^{1}$ In the context of infectious diseases, a vector is "an organism, typically a biting insect or tick, that transmits a disease or parasite from one animal or plant to another" (OUP n.d.).
} 
citizens to engage in irrational and excessive purchasing and often stockpiling of health-related items as a precautionary measure. Often these items are totally disconnected from the main problem and are unrelated to risk resolution (Mao 2020). However, the stockpiling of some products, such as facial masks (Leung et al. 2020), creates shortages which then pose an additional threat to effective healthcare. As the first author of this article has noted elsewhere (Lopes 2020), while the fabric masks do in fact play an important role in the prevention of transmission, excessive purchasing of professional medical masks by the general public has resulted in depleting the supply of facial masks and consequently adversely impacted on situations, especially in medical contexts, where they are urgently required. Thus, the COVID-19 pandemic highlights the need for knowledge and information management to ensure that citizens have sufficient clear and reasonable information to guarantee that they change their behaviour in order to prevent the spread of infection (Legido-Quigley et al. 2020).

While the actual spread of the virus is indeed a significant health danger ( $\mathrm{Wu}$ and McGoogan 2020), the impacts of the pandemic are reaching far beyond the medical (physical and mental) sphere and have wide ramifications and social consequences that extend the risk to the destruction of livelihoods (OECD 2020, WHO 2020a). The past few months have already demonstrated in very real terms the immense socio-economic repercussions of the COVID-19 virus and the significant economic risks it poses (Kock et al. 2020). It has threatened cohesion both on the level of international social communities and within societies themselves (Lancet 2020), featuring high levels of social disruption beyond what has been recorded since the last great world pandemic in 1968 (Bell 2020). ${ }^{2}$

\section{The adverse effects of export bans on personal protective equipment (PPE)}

Healthcare systems and their entire supply chains are being pushed to the limit. For the first time, there are export bans on clinical protective material (Henley 2020). Never before, even among countries in conflict, with the exception of the United States' medical embargo imposed on Cuba in $1960,{ }^{3}$ have countries refused to export clinical products. Now, with reserves of essential material at risk in the face of the current pandemic, many countries (such as Germany, Kazakhstan, Russia) have prohibited exports to others, even those who are much worse off than they are. This is because healthcare systems are struggling to look after high numbers of contagious patients whose care requires using and disposing of vast amounts of material

\footnotetext{
2 “Three pandemics occurred in the previous century: 'Spanish influenza' in 1918, 'Asian influenza' in 1957, and 'Hong Kong influenza' in 1968. The 1918 pandemic killed an estimated 40-50 million people worldwide. That pandemic, which was exceptional, is considered one of the deadliest disease events in human history. Subsequent pandemics were much milder, with an estimated 2 million deaths in 1957 and 1 million deaths in 1968" (WHO 2007, p. 2).

3 Despite efforts made in 2015 by the then presidents of the United States and Cuba, Barack Obama and Raúl Castro, at the Seventh Summit of the Americas to lift the embargo progressively (Drain 2015), the embargo was subsequently re-imposed.
} 
resources as well as many hours of medical personnel's attention (Adams and Walls 2020).

In addition, the first studies (many of which are still appearing mainly in newspapers and various types of grey literature $)^{4}$ show that due to all the attention being focused on COVID-19, patients with other conditions are either unable or afraid to access hospitals, giving rise to drastic increases in mortality rates among patients with other ailments - mortality rates that are possibly greater than those of the pandemic itself (Marzocchi 2020).

The pandemic did not take long to impact on health professionals; the exponential rise of patients requiring healthcare services has resulted in the infection of countless frontline professionals (Remuzzi and Remuzzi 2020) due to their proximity and exposure to the virus. By consequence, approximately 10 per cent of those who have been infected are in fact health professionals (ibid.). Death reports of health professionals due to exhaustion have also been registered (Boseley 2020).

\section{How it started: the evolution of the COVID-19 pandemic}

A novel coronavirus, SARS-CoV-2, emerged in December 2019 in the central Chinese city of Wuhan and surrounding Hubei province, where more than half of global cases had been recorded (Hageman 2020) at the time of writing (April 2020). China was able to mobilise its immense reserves of civilian and military clinical manpower (WHO 2020b) to set up several large hospitals in record time and in proportions that very few countries in the world would be able to replicate.

Subsequently, South Korea also managed to flatten the epidemic curve with a unique strategy: it introduced a massive education and training campaign on the importance of wearing masks and taught the population how to manufacture masks made of fabric. South Korea also placed strong restrictions on citizens' movements, so that people would only go out to obtain essential products or services and only while wearing a mask. The city of Osan provides a good example of how the training was accompanied by a thorough testing process for everyone who was in contact with an infected individual (Lopes 2020).

While cases have been confirmed in every member state of the European Union, two of the hardest-hit countries, Italy and Spain, implemented total lockdown measures which are only just being cautiously eased as we write. As new cases continued to emerge, healthcare services in many other European countries were also struggling to avoid burning out: the United Kingdom, the Netherlands, Switzerland, Luxembourg, France and Norway.

Even in the least affected countries, healthcare systems have had to take measures such as postponing non-urgent clinical procedures, and hospital staff and testing laboratories are overburdened. Naturally, in countries with more fragile healthcare

\footnotetext{
4 The term "grey literature" refers to reports, working papers and other items not published by professional publishers. Items of grey literature are not usually circulated to (or known by) many readers beyond those affiliated to the institution they were produced by, and therefore such items are at times difficult to track down.
} 
systems, the limit of the response capacity will be reached much faster, particularly in intensive care units, which have been the critical element of the clinical struggle in countries where the pandemic is more advanced. Once intensive care units are overburdened, the mortality rate skyrockets.

Unsurprisingly, the epidemic was upgraded to a pandemic on 11 March 2020 by the World Health Organization (WHO) $)^{5}$ due to the "worldwide spread of a new disease" and the increased number of cases of infection in multiple parts of the world (Remuzzi and Remuzzi 2020).

\section{Why are countries' responses to disasters so limited?}

While one is tempted to believe that humanity will somehow deal with and eventually overcome this pandemic, as it has done with all previous ones, and that, except for the risk of a mutation of this virus, it will pass with greater or lesser negative impact (Jones 2020), the "picture" described above expresses something much more profound: Humanity is permanently exposed to outbreaks that arise from time to time in localised or epidemic patterns, and poorer countries are more likely to be affected by an epidemic than more prosperous ones. Therefore, life conditions of our species on planet Earth are inherently associated with epidemic - or pandemic - episodes that countries have to deal with at different points in time, a necessity which will arise again in the future, possibly with increasing frequency (Vargas 2020).

While epidemics are more common among the poorest countries, there nevertheless appears to be no appropriate preparation for a larger-scale pandemic among countries regardless of their level of development. The capacity to prepare citizens to go beyond dealing with small or medium outbreaks of infectious diseases has so far not proven satisfactory, not even in the most economically and scientifically advanced countries.

Why are countries' responses to disasters so limited? Different causes contribute to this, but one is that the entire effort is based on the extent of health structures' capacity to intervene in situations where levels of citizen engagement are low. Usually, there is no collective, social action to respond to this kind of crisis. In most countries, the role of citizens is considered to be a passive one - they are expected to respond to indications provided by established healthcare structures rather than being active participants in their own healthcare regime.

\section{A need for collective, social action}

In this article, we argue that health and well-being are too important and complex to reside only in one national organisational system, however sophisticated a country's

\footnotetext{
5 According to the Dictionary of epidemiology, an epidemic is defined as "the occurrence in a community or region of cases of an illness, specific health-related behaviour, or other health-related events clearly in excess of normal expectancy" (Porta 2014). A pandemic is defined as "an epidemic occurring worldwide, or over a very wide area, crossing international boundaries and usually affecting a large number of people" (ibid.).
} 
health system may be. For a response to a serious threat to the health of a population to be systemic, it needs to be conceptualised as the organic response of a country's entire society and all social institutions in which citizens are active participants.

In order to establish how information can be managed in order to change behaviours effectively, we need to include the social factor in our considerations and redefine the role of the citizen. These elements are fundamental to our understanding of the social dimension in all pandemic health risks.

There are basically two ways to contain a localised risk: First, by using high containment measures that force citizens to remain in one place, and second, by leading citizens to adopt appropriate behaviours and attitudes to a particular situation. Past experiences such as a country's history in terms of diseases, culture, etc., work as mediators that influence the acceptance of such measures (Lancet 2020).

For the latter approach to be effective, the citizenry needs to have a sufficient level of prior education in order to understand the risk level and to benefit from the dissemination of health information. Education and specifically health literacy are necessary to enable citizens to use knowledge to act appropriately and in a way that is necessary for one's personal defence and the defence of those for whom one is responsible. Health literacy in the context of a pandemic or epidemic refers to the possession of literacy skills that are required to make informed health-related decisions in a variety of different environments. These skills enable individuals to obtain, understand and use information to make decisions and take actions that will have an impact on their health status (Nutbeam 2000).

However, the COVID-19 pandemic also shows that it is no longer sufficient for a single country to be properly prepared in the two above-mentioned ways of containing a localised risk because of the global ramifications of pandemics. As has been noted in the current pandemic, it needs to be ensured at an international level that citizens have the knowledge, attitudes and perceptions necessary to adopt riskmitigating behaviour. At the time of writing this article (April 2020), 203 countries and autonomous territories worldwide had incidences of COVID-19, which were a result of large-scale international migration and travel for professional and tourist purposes (Hageman 2020). Ironically, in the developing world, incidences of transmission have come from well-heeled, well-educated tourists who returned to their home country unaware that they were infected and then exposed unsuspecting and unprepared third parties on their return to their place of residence or work. In this way, they became a vector of the disease and a pathological vector for the rest of society, necessitating a systemic response at an international level.

In the next section, we aim to demonstrate the crucial role of adult learning in national and international efforts both in overcoming the current pandemic and in preparing the global community for possible future ones. 


\section{Adult learning and education - a natural instrument to improve safety in health and well-being}

The United Nations Educational, Scientific and Cultural Organization (UNESCO) perceives adult learning and education (ALE) as a means to help tackle pressing economic, social and environmental challenges, and argues for promoting stronger ALE policies and practices in UNESCO Member States (UIL 2020). Many of these Member States are developing countries that still have large numbers of low-literate adults, despite efforts to improve literacy rates in the context of large-scale literacy agendas such as the UNESCO-led education for all (EFA) initiative promoted in 2000-2015.

This appeal resonates with the current United Nations 2030 Agenda with its 17 Sustainable Development Goals (SDGs) (UN 2015). Dedicated to education, the fourth of these goals, (SDG 4), calls for the promotion of lifelong learning (including ALE), particularly in developing countries where ALE is important for those who have been excluded from acquiring, or have failed to acquire, basic competences through formal schooling (UIL 2009, p. 67).

Amina Osman et al. (2017, p. 23) state that the benefits of education and health for individual life opportunities and societal advantages are widely known. They also point out the strong mutually reinforcing relationship between education and health, where improvement in one has clear positive impacts on the other. A country's national well-being is measured by how well it succeeds in furthering the health of the majority of its population. Education and indeed ALE can contribute to equipping citizens with life skills that are critical for improving and maintaining their health and well-being. By disseminating information and health messages about nutrition, substance abuse and emergency plans to promote health and to mitigate health risks, particularly among women and rural and minority groups in contexts of poverty (especially in the Global South), these disadvantaged groups can be reached and included. ALE, which includes the promotion of literacy and numeracy, provides critical foundational components for addressing challenges that persist among the poor, wherever they are, regardless of their country's national gross domestic product (GDP).

In his recently published book, The Cruel Pedagogy of the Virus, Portuguese sociologist Boaventura de Sousa Santos (2020) reflects on the impact on the world as it is being plunged into crisis by the virus, and he considers the long-term prospects this may have. De Sousa Santos identifies the intrinsic inability of many current economic systems to face the challenges caused by the pandemic, revealing the deep social, economic, political, cultural, environmental and educational inequalities resulting from a focus on the market at the expense of ensuring that the basic needs of the population and the planet are met.

\section{Poor citizens and elderly people are particularly vulnerable}

While many commentators argue that the virus is largely indiscriminate, the Guardian newspaper's United States southern bureau chief Oliver Laughland (2020) refers 
to the high mortality rates in Louisiana, which suggest a racially disproportionate per capita death rate among America's poorest. As he states,

seventy per cent of those who have died here are black, despite African Americans making up only $32 \%$ of the state population (ibid.).

He attributes this to the

nexus of intergenerational poverty [in the deep South of the United States], a greater prevalence of underlying health conditions, and less access to healthcare [which] are certain to have more pronounced consequences for the black community as the virus proliferates (ibid.).

This is resonated by The Economist's discussion on 18 April 2020 of how American inequality offers unequal protection in the face of COVID-19, arguing that the pandemic amplifies existing gaps in protection since the calamity is "two-pronged - a contagious sickness first, followed by an economic malaise" (Economist 2020) - affecting those who are amongst the poorest, regardless of their country's GDP. As Human Rights Watch (HRW 2020) points out, the COVID-19 outbreak has exposed the depth of socio-economic cracks in societies, revealing how economic inequalities and fragile social safety nets leave vulnerable communities to bear the economic brunt of the crisis:

While the virus infects people regardless of wealth, the poor will be most affected due to longstanding segregation by income and race, reduced economic mobility, and the high cost of medical care. Low-income communities are more likely to be exposed to the virus, have higher mortality rates, and suffer economically. In times of economic crisis, these vulnerabilities will be more pronounced for marginal groups - identified by race, gender, and immigration status (HRW 2020).

Another observation is that the impact is closely linked to the age demographics of countries, with the greatest impact being on populations over 60 years of age. This demographic should guide the identification of this niche group to be targeted by ALE. The interventions for this group should be tailored to their risk profile and provide knowledge-generating responses to their specific need to increase self-protection as well as provide the methods for doing this.

\section{Democracy, civic participation and national health (education) expenditures}

While the effect of the pandemic on the least wealthy countries in the Global South is severe, calibration of infection rates is nebulous as countries struggle to test for the virus and trace contacts. In statistical terms, a regression of the large number of identified predictors seems to suggest that what appears to be the most robust scenario for flattening the infection epidemic curve at this stage (April 2020) is a high degree of democracy and civic participation. It can be inferred from this insight that lifelong learning and a focus on ALE will become more critical for the poor, regardless of their geographic location. 
Health spending has steadily increased since the end of World War II. In 2016, it was 10,023 billion USD (WHO 2020c) with a sustained average annual growth of 137 billion USD (ibid), this represents 5.5 per cent of world GDP. Nevertheless, there are large asymmetries in health expenditure. The richer the country, the greater the percentage of its GDP which is allocated to health. Greater expenditure does not, however, automatically translate into better quality healthcare, because the high cost is often absorbed by a high waste rate and high prices, thus reducing the quality of health care to levels similar to those of less rich nations.

More often than not, the share of a country's GDP allocated to public health is only a small fraction of the total health budget, generally assumed among professionals to range between about 1 and 4 per cent of total health expenditure (Himmelstein and Woolhandler 2016), and depending on whether (or not) vaccination costs are included in the costing.

What the COVID-19 pandemic has revealed starkly is that preventive health, and in particular public health, needs to be improved immensely in order to prepare nations for overcoming disasters of this magnitude. It is also clear from the current crisis that the costs of investing in education towards healthy populations are so low that they may not be used as an indicator to compare health systems. In this article, we argue that health education, as part of lifelong learning, is in fact a critical part of the toolkit for disaster management, including management of the current pandemic. We thus argue for the importance of ALE as part of the process of improving levels of health literacy, necessary for people from all strata of society.

\section{The life stage model of health education}

While education, as mentioned earlier, is explicitly addressed in the fourth of the seventeen SDGs,

Ensure inclusive and equitable quality education and promote lifelong learning opportunities for all (UN 2015, p. 19),

the UNESCO Institute for Lifelong Learning's policy brief on Literacy and numeracy from a lifelong learning perspective also refers to the role of lifelong literacy as a crucial catalyst in achieving the other sixteen SDGs.

Lifelong literacy covers the full spectrum of lifelong and life-wide learning and involves a continuum of proficiency levels that require institutionalized learning systems which are flexible and support integrated approaches at all stages of a person's life and in a diversity of life situations ... [It] requires a cross-sectoral approach cutting across all development relevant areas (health, agriculture, labour, social security, environment, culture, etc.), beyond the education sector (UIL 2017, p. 3; emphases added).

In the same vein, the Education Section of the Health and Education Unit within the Commonwealth Secretariat ${ }^{6}$ developed a Curriculum Framework for the Sustainable

\footnotetext{
6 According to the website of the Commonwealth, a "voluntary association of 54 independent and equal countries" headquartered in London, "the Commonwealth Secretariat is the intergovernmental organisation that supports member countries to achieve the Commonwealth's aims of development, democracy and peace" (https://thecommonwealth.org/about-us/secretariat [accessed 24 May 2020]).
} 


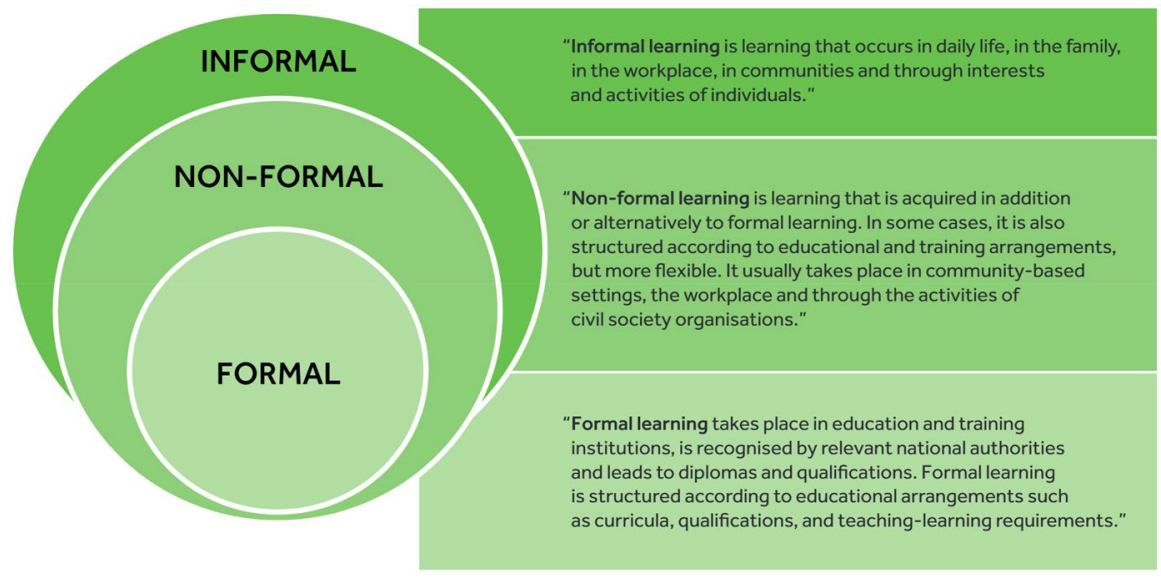

Fig. 1 The different forms of learning. Source: Osman et al. (2017, p. 8; adapted from UIL 2012)

Development Goals three years ago "to support member countries in addressing all 17 SDGs through education and learning” (Osman et al. 2017, p. iii). This curriculum framework is designed for integrating the teaching of disaster preparedness at all levels of formal and informal education systems in order to tackle the various SDGs. Figure 1 illustrates the interrelationship of the three domains of lifelong learning, namely formal, non-formal and informal learning.

These three domains give rise to what Osman et al. (ibid.) refer to as the life stage model of learning (where variable health and disaster awareness topics can be integrated) within what they term the life course approach and across the stages of lifelong learning, with a cumulative effect.

The life course approach aims to assist learners in developing the skills they will need for learning, life and work in an evolving world with ever-changing challenges, based on the perspective that each life stage exerts an influence on the next, combined with social, economic and environmental influences throughout the life course (Osman et al. 2017, p. 7).

With regard to health awareness in the context of the SDGs, the World Health Organization (WHO 2016, p. v) refers to those health challenges that persist in developing countries, such as high maternal and child mortality rates, malnutrition, and high incidences of communicable diseases such as HIV/AIDS and tuberculosis - to which we must now add the global threat of COVID-19 (Hageman 2020). 
Table 1 Components of health literacy: Health learning topics at various life stages

\begin{tabular}{|c|c|}
\hline Life stage & Health topics \\
\hline Childhood & $\begin{array}{l}\text { Personal hygiene, exercise and healthy eating } \\
\text { Basic emergency preparedness and evacuation drills } \\
\text { Home and road safety } \\
\text { Unhealthy environments } \\
\text { Food hygiene and sanitation } \\
\text { Disease transmission and prevention (including handwashing) } \\
\text { Anti-violence and bullying prevention }\end{array}$ \\
\hline Adolescence & $\begin{array}{l}\text { Communicable diseases } \\
\text { Nutritional intake } \\
\text { Lifestyle choices } \\
\text { Substance abuse } \\
\text { Reproductive health and rights } \\
\text { Environmental effects on health } \\
\text { Emergency preparedness, evacuation drills and basic First Aid } \\
\text { Mental and emotional health }\end{array}$ \\
\hline Adulthood & $\begin{array}{l}\text { Foodborne illnesses } \\
\text { Nutrition } \\
\text { Chronic, communicable and non-communicable diseases } \\
\text { Disease prevention } \\
\text { Emergency response and preparedness } \\
\text { Recognising signs of physical and emotional abuse } \\
\text { The relationship between health, the environment and climate } \\
\text { change } \\
\text { The importance of lifelong physical activity } \\
\text { Workplace occupational health } \\
\text { Maternal health } \\
\text { Neonatal and child health care } \\
\text { Positive parenting techniques } \\
\text { Children's inoculation (vaccination) } \\
\text { Mental and emotional health }\end{array}$ \\
\hline Older age & $\begin{array}{l}\text { Chronic health conditions } \\
\text { Nutrition } \\
\text { Cognitive health. } \\
\text { Physical injury } \\
\text { Cognitive health } \\
\text { Oral health } \\
\text { Mental and emotional health }\end{array}$ \\
\hline
\end{tabular}

Note: This table is based on Osman et al. (2017, p. 8)

\section{Literacy and health literacy}

Literacy, education and health literacy are regarded as essential for promoting maternal and child health, preventing the spread of communicable diseases, and promoting immunisation (Nutbeam 2000, p. 263). In his article entitled "Health literacy as a public health goal" (ibid.), Don Nutbeam draws attention to the important benefits of health literacy; these include the application of literacy skills to improve adults' ability to engage with health-related messages and comply with these when, for example, taking prescribed medication, following the dosage instructions on 
medicine labels, reading appointment cards, and understanding guidelines for home healthcare (ibid.). This list immediately demonstrates that a lack of health literacy clearly poses problems for patients with chronic illnesses.

Table 1 highlights components of health literacy that relate to the various life stages in our teaching endeavours towards achieving SDG 3 - "Ensure healthy lives and promote well-being for all at all ages" (UN 2015, p. 18).

Nutbeam points out in this regard that health literacy does more than enable people to engage with texts relating to health matters; rather, he states that

by improving people's access to health information and their capacity to use it effectively, health literacy is critical to empowerment (Nutbeam 2000, p. 264).

We argue that literacy is an indispensable tool for enhancing health knowledge. Clearly, literacy education is context- and time-specific, but there are sufficient generic skills, knowledge and attitudes that can contribute to the prevention of communicable diseases.

The relationship between low literacy and a range of health-related outcomes is well established. Low- or non-literate individuals are less responsive to health education, less likely to use disease prevention services, and less likely to successfully manage chronic disease.

As mentioned earlier, in the context of an epidemic or a pandemic, health literacy, which is one aspect of ALE, enables individuals to obtain, understand and use information to make decisions and take actions that will have an impact on their health status. We contend that ALE is the only tool capable of mitigating a pandemic such as COVID-19 for a number of reasons:

1. As we have shown above, the behaviour of the individual ultimately decides the variables in terms of a pandemic's dissemination, thus determining the scale that pandemic might reach.

2. The current formal education systems in place in most countries around the world are still far from able to respond to the need to prepare learners - future adults - for situations such as pandemics or other emergency risks endangering both personal and social life. While some health topics may be part of formal curricula in some countries, emergency preparedness, evacuation drills and even basic First Aid training are rare.

3. ALE can fill the gap left by formal education systems and can be adapted to populations with different levels of schooling, including people who have either not completed formal schooling or never attended school at all; it can thus become the tool of choice for preventive healthcare for entire populations.

4. Furthermore, when society is faced by a threat, ALE can be tailored to each specific situation - ideally by teaching preventive measures, but also in tackling an ongoing crisis both in terms of treatment and in stifling recurrent outbreaks in society. 
5. ALE can be implemented through different platforms as a complementary solution, thus reaching multiple audiences directly, ensuring what is somewhat enigmatically termed "redundancy of communication", etc. ${ }^{7}$

6. ALE can be adapted to different social roles, such as caregivers and political decision-makers as well as those who work in formal and traditional healthcare.

Therefore it is reasonable to argue that ALE should in fact be understood as an element of national preparation for emergencies. There are two aspects to this: the first focuses on prior preparation, and is generic and corrective in relation to the limitations of formal education systems; the second focuses on reacting in an emergency to a given risk and on specific social roles and can take on multiple forms in its implementation.

\section{ALE as a basic instrument for preparing for and addressing national emergencies}

In our understanding of ALE as a tool for tackling the COVID-19 pandemic, we now focus on the six underlying conditions that pertain to the pandemic, which correspond to the six reasons we listed in the previous section for ALE's particular suitability for mitigating a pandemic.

\section{First, individual behaviour ultimately determines the spread and scale of the pandemic}

In order for populations (and individuals) at risk to acquire knowledge of a sufficient depth to enable behaviour change that is useful for their personal protection and the protection of those for whom they are responsible, adequate literacy and numeracy skills are essential tools. Citizens without these skills will not be able to correctly understand official health information, or demystify unofficial health information that evolves with pandemics. As is often the case with large-scale problems, citizens are faced with contradictory messages, and in the context of pandemics, they are required to filter out fake news and the myths that proliferate at times of social distress. Myths and misinformation, spread fast and unchecked to vast audiences through the relatively new channels of social media, have exacerbated the problems of health authorities in dealing with the current COVID-19 pandemic (Depoux et al. 2020). Moreover, since the COVID-19 pandemic is more than a health matter and is in fact having considerable socio-economic impacts around the globe, the strategy needs to go beyond medical measures. Solutions inevitably need to address social

\footnotetext{
7 Contrary to what the term redundant communication seems to suggest, it refers to an element which is in fact critical for successful communication. Originating in $1960 \mathrm{~s}$ marketing, where it was found that an advertising campaign was particularly successful if it was run in parallel on a number of different channels such as on TV, in magazines, on billboards etc., this particular idea of "redundancy" is now applied to other situations (teaching in class, emergency preparation in hospitals etc.) where it is important to get a message across fast and with lasting impact.
} 
and economic factors as well. Danielle Aldrich and Michelle Meyer (2015, p. 2) argue that at times of disaster, resilience is the feature which enables individuals and communities to face and manage the negative pressures that impact on them, and to successfully cope with and navigate crises. They point out that the development of resilience in situations of despair always has both an aspirational aspect and a learning element (ibid.).

\section{Addressing the risk factor of low literacy}

The social aspect of dealing with disasters requires behaviour change from all citizens in line with newly emerging information. Transforming information into new behaviours may be cognitively challenging and requires literacy and numeracy skills to enable citizens to read, understand and interpret instructions, and to calculate and measure, among other abilities. Without these skills, pandemics will spread at the pace of citizens' unpreparedness (Nutbeam 2015).

Research conducted by the second author of this article (McKay 2018, 2019, 2020) on more than four million newly literate adults provides evidence of the contribution that literacy and numeracy make to the improvement of health knowledge, attitudes, perceptions and behaviour. The research, conducted in South Africa, explored the impact of (health) literacy as a component of a mass literacy campaign which integrated health themes. These aimed to resonate with health and wellbeing (SDG 3) and empower learners in relation to healthcare, especially women ("Achieve gender equality and empower all women and girls", SDG 5; UN 2015, p. 20) by focusing on personal and household hygiene, health-seeking behaviour, knowledge about vaccinations, nutrition, pregnancy, reproductive health and HIV/ AIDS.

The target group of newly literate adults showed improved understanding of their chronic illnesses such as diabetes, hypertension and communicable diseases, and learners reported that they had a better understanding of how AIDS and tuberculosis (TB) are spread. Learners expressed what their newly acquired health knowledge enabled them to understand:

"I know when to take my pills and how much I must take. I know what to do if I miss taking my pills ..."

"I can read the pamphlets I get from the clinic and I know the date of my next clinic visit ..."

"I know that I must not eat sugar food. I can read the posters on the wall at the clinic."

(McKay 2020, p. 9)

The research (McKay 2018, 2019, 2020) demonstrates that 87 per cent of the more than four million newly literate adults perceived that they had a better understanding 
of nutrition, and 88 per cent perceived that their knowledge of health issues had improved and that they understood health messages better (ibid.). Since citizens with low levels of literacy are highly vulnerable due to being unable to engage with health messages, ALE is paramount in addressing any pandemic.

In research published elsewhere (McKay and Romm 2007, 2008 and McKay et al. 2003) the second author and colleagues refer to the critical need for basic literacy skills. The purpose of their studies, conducted on behalf of the International Labour Organisation (ILO), was to establish the knowledge, attitudes, perceptions and behaviour of informal sector ${ }^{8}$ workers working in the streets, in markets, or at taxi ranks in South Africa and Zambia. The majority of these workers sold goods such as clothing or food products, or offered services such as hair styling or shoe repairs through unregulated one-person or micro enterprises. The intention of this research was to ascertain these workers' knowledge and attitudes in relation to HIV/AIDs and to determine vulnerabilities and appropriate health and education interventions specifically designed for this target group. Informal sector activities are the dominant forms of income generation in developing countries with low literacy rates, with most informal workers being sole breadwinners feeding a high ratio of dependents. The researchers conducting this study argued that low levels of literacy had implications for any proposed HIV/AIDS- or health-education interventions and that this was exacerbated by the levels of literacy and the choice of language/medium of instruction being employed in such interventions. Other challenges in reaching and teaching this target group were exacerbated by the fact that many were refugees and internally displaced, highly mobile, and that their living circumstances made them particularly vulnerable to HIV/AIDS. Their context was important in designing the content and the mode of presentation of the training intervention.

In the context of the COVID-19 pandemic, governments in Southern Africa are being pressured to grant permission for informal sector economic activities to recommence. In the absence of the strict application of the protocols of social distancing, sanitising and the use of masks, lifting the "lockdown" on this economic sector and amongst this particularly vulnerable group will have massive ramifications for the spread of the virus. Lessons from the endeavours to mitigate HIV/AIDS in South Africa, one of the most-affected countries worldwide, are important here. ${ }^{9}$ Most Southern African countries used mainstreaming approaches to deal with HIV/ AIDS, ensuring that educational interventions cut across the lifelong learning continuum (i.e. the three forms of learning depicted in Fig. 1). To do this, countries

\footnotetext{
8 According to the definition of the International Labour Organization, "The informal sector may be broadly characterised as consisting of units engaged in the production of goods or services with the primary objective of generating employment and incomes to the persons concerned. These units typically operate at a low level of organisation, with little or no division between labour and capital as factors of production and on a small scale. Labour relations - where they exist - are based mostly on casual employment, kinship or personal and social relations rather than contractual arrangements with formal guarantees" (ILO 1993, section 5. (1)).

9 South Africa's medical approach to combating this health hazard was to launch the world's largest antiretroviral treatment (ART) programme in 2004 (Boulle et al. 2008), which has already proven to be effective in raising life expectancy (Nakkazi 2019). The ART programme goes hand in hand with a number of awareness-raising campaigns, including tuberculosis and treatment compliance campaigns.
} 
relied on all educators, including adult educators, literacy educators, community development workers, community health workers, extension officers and peer educators, to disseminate carefully designed interventions. It was found that the training of peer educators in this sector offered many benefits, since they were easily accessible for training and for dealing with information needs when they arose (McKay and Romm 2008). While these endeavours did yield positive results in the context of HIV/AIDS, the emergency of the COVID-19 situation is somewhat different. The limitations brought about by social distancing, with the consequent closure of educational institutions and adult education centres, has made it particularly difficult to target those with low levels of education during the COVID-19 pandemic at a time when citizen knowledge and comprehension is necessary for compliance and for "managing the curve".

Discussions on who should carry out this critical task of mitigation education differs from country to country. In South Africa, 28,000 community healthcare workers were mobilised and trained to conduct screening and testing in high-density and high-risk areas (Mafuma 2020). Some formed part of an existing team of community workers, while others were recruited and trained specifically for this purpose. Those who were already in the system had prior experience from performing various tasks, including tracing of HIV or TB treatment defaulters, and others were specially recruited and trained for the COVID-19 response. While their work is primarily to test people and trace the contacts of those infected, by implication, they are also required to disseminate health information to communities, and may be considered one of the primary groups of actors in ensuring ALE as they conduct door-to-door visits (Mafuma 2020).

\section{Addressing the risk factor of women's low education levels}

Of particular relevance in this context is the general low level of women's education in developing countries, since the tasks and responsibilities related to family health traditionally rest with them. Most cultures place the woman in the family at the centre of decision-making in questions concerning health for both immediate and extended family members, putting women at greater risk (not least in terms of contagion, making the right decisions and implementing correct care measures, etc.) than men.

The elderly, the population that constitutes the highest risk in terms of COVID19 , are also a "natural burden" for women, often transcending some social taboos or traditional practices. For example, it is common for women in the family to take care of elderly, bedridden family members' hygiene, regardless of their gender. Women are often allocated the role of being carers or responsible for the physical hygiene of family members and for household hygiene - both of which are vectors in the COVID-19 pandemic and require skills to protect the carer. 


\section{Second, the current formal education system fails to prepare learners for crises and disasters}

In responding to the need to prepare young learners - future adults - for situations such as pandemics or other emergency risks that endanger personal and social life, it is necessary that formal education systems, i.e. regular schools, integrate learning about disaster management into their curricula.

Formal education systems are primarily focused on preparing people for the labour market, and little or no learning is related to citizenship or individuals' capacity as social actors to take collective action in critical or emergency situations. Although such learning is inherent in the SDGs (UN 2015), there is little in formal school curricula that prepares learners for future disasters or for being social actors in a future collective health defence system. Any training that does exist in this dimension is restricted in most countries to basic notions of food security and general health. Very little formal education addresses preparation for dealing with emergencies or national disasters.

However, even if this training is provided to learners in later stages of life, it is never too late. It still enables making a difference, imparting relevant skills which can be applied in the context of a more intimate connection with family life, the responsibilities of each individual in society, the problems that the individual learner faces, and can address how they, as members of a family or other collective entity, are required to take co-responsibility in times of national disaster (Vandemoortele and Delamonica 2000). Allowing children back to school requires intensive interventions to prepare these learners to return to the public space. They have to be provided with knowledge about how to ensure their own protection and the protection of others in school, on school transport and at home. Learners and teachers alike need this critical training on all health protocols as educational institutions and auxiliary services begin to open again.

\section{Third, ALE can fill the gaps left by the schooling system}

Given the limitations of formal schooling systems in preparing future adults for dealing with social disasters, as mentioned above, we contend that ALE can fill the gaps in formal education and can be adapted for populations with different levels of schooling, making ALE the tool of choice for preventive healthcare for entire populations. The goal of ALE in a situation like the COVID-19 pandemic is to develop disaster-resilient communities. ALE interventions, through both formal and informal education (in addition to reaching learners in schools), are the best way to ensure that messages reach into every home and community.

Particularly in countries where average literacy levels are low, ALE can play a critical role as these are usually the same countries in which healthcare systems are more fragile. While there is a need in any case for investments to be made in 
adult literacy and numeracy programmes, ALE can also assist countries in filling the knowledge gaps left by formal education systems - thus providing support urgently necessary to enable effective healthcare during times of social disaster. In turn, it is possible to establish a virtuous circle, because useful knowledge to protect oneself and family members for whom one is responsible is usually a highly attractive reason to return to some form of education, be it formal or informal.

As with all forms of education, significant differences in educational methods, media and content will result in different learning outcomes. Improving health literacy involves both the transmission of health information and support towards developing confidence to act on knowledge and information (Nutbeam 2015, p. 1). ${ }^{10}$

\section{Fourth, when society faces a threat, ALE can be tailored to each specific situation}

Each pandemic or other collective risk situation (earthquakes, tornados, floods, bush fires, among others) has its own characteristics and unique needs. In responding to such situations, the design of the respective ALE interventions must take into account both the clinical and the sociodemographic characteristics so as to determine what information should be provided to the population. In fighting the Zika pandemic, ${ }^{11}$ for example, the information campaign centred on pregnant women and perinatal healthcare. In the fight against the Dengue virus, ${ }^{12}$ information focused on the dangers of stagnant water pools and on how to recognise the transmitting mosquito. Combating Ebola virus disease mainly involves teaching hand hygiene (WHO n.d.). ${ }^{13}$

In respiratory infections such as the current COVID-19 pandemic, the ethical protocol for coughing and sneezing with minimal risk to others, and reasons for social distancing and adhering to lockdown protocols all form an essential part of the health messaging that needs to be disseminated to all strata of society. All ALE interventions need to take into account the manifestation of the disease and the infection patterns. It is important that information campaigns highlight the source of the risk and draw attention to the desired behaviour in hazardous situations.

Each specific hazard should automatically trigger a knowledge-generating response via ALE, focused on critical information that citizens should receive, depending on their condition and social role, to mitigate the consequences of a determined risk.

In the current COVID-19 pandemic, the struggle will ultimately be won by training citizens how to avoid creating secondary transmission chains. It is unlikely that the solution will lie solely in the application of clinical resources as has been seen

\footnotetext{
${ }_{10}$ For some skills, i.e. First Aid training, learners' confidence can also be regained by their engagement in a refresher course.

11 The Zika pandemic was caused by a mosquito-borne viral infection in Brazil in 2015 (WHO 2018).

12 Like Zika, Dengue fever is also a mosquito-borne viral infection (WHO 2020d).

13 The Ebola virus disease (WHO n.d.) has still not been combated (WHO 2020e). The virus is transmitted to people from wild animals (e.g. fruit bats) and then spreads in the human population (WHO n.d.), The World Health Organization offers online "knowledge resources for responders"; see https://openw ho.org/courses/knowledge-resources-ebola [accessed 27 May 2020].
} 
in China, South Korea, Italy and Iran, all of which were rapidly exhausted with the influx of many complex cases in a short time.

\section{Fifth, ALE can be implemented through different platforms as a multimodal, multi-targeted intervention}

Using multimodal platforms will enable (health-related) ALE interventions to reach multiple audiences. Suitable multimodal platforms include, for example, different print and audiovisual media, including social media and mass media such as television and radio. Translating new knowledge into new behaviours in circumstances of disaster is challenging. For this reason, it is essential to provide adequate, clear information through a credible source (Thompson 2019), taking into account the concept that communication is successful (or not), depending on the "communication axis" along which it is transmitted. This concept defines the degree to which each of the various media platforms (i.e. channels of "redundant communication") properly reach a targeted audience. In the case of COVID-19, the target audience comprises all people directly or potentially affected by the pandemic, i.e. entire countries' populations. The vastness of this target group and the variety of the information channels they regularly consult makes the dissemination of information more complex. It is necessary to strengthen research efforts to identify the various subsectors and their knowledge gaps.

The importance of inclusive information is increasing, since it has become a fundamental element of communication in the event of a crisis. Particularly in countries where health structures are more fragile or social systems are under great stress, the near ubiquitous use of mobile phones is often significant, and both real-life and virtual social networks are fundamental ways of communicating with the population (Handmer et al. 2019). The situation is not linear, since digital communication networks are also usually the channel through which fake news and misinformation are disseminated, a situation that requires a strong and enlightening presence.

\section{Sixth, ALE can be adapted for different social players}

As we are seeing during the current COVID-19 pandemic, the necessity arose to offer training at short notice to those who fulfil different social roles, such as caregivers and political decision-makers as well those who work in formal and traditional healthcare. In addition, there are specific healthcare roles such as those (traditionally) carried out by family members that need to be identified for targeted training. There are still many other essential roles/functions that need to be identified as a priority in using ALE as a health and national security tool. Below, we highlight seven relevant target groups, each of whom play different roles. 


\section{Healthcare professionals}

One lesson that the current COVID-19 pandemic has already taught us is that it becomes difficult, in a very short time, to provide professional training to healthcare professionals. ALE can and should play a crucial role in ensuring that the healthcare sector possesses training structures for prompt and almost daily knowledge updating. This is necessary because the strategy to manage a pandemic continually changes and the healthcare professions, including nurses, pharmaceutical, hospital janitors, etc., are required to navigate and present different ways of accommodating these changes in dealing with the problem. In the present pandemic, classic procedures have had to be adapted to the new problem, and this gives rise to protocols that need to be disseminated instantly and revised as the need arises. This is especially pertinent to healthcare workers from other hospital areas who are brought to the centre of the pandemic to reinforce health services. Many of these do not have the necessary preparation for working in pandemic conditions and require specialised training. In the COVID-19 context, we are talking about enormous numbers of professionals, hundreds of thousands worldwide, who within a week or two must be properly prepared. The usual professional training structures are not designed for sudden and massive reactions. ALE's experience is therefore fundamental.

\section{Political actors}

Governments and politicians have a critical role to play in mobilising local action, and they are required to react promptly and under enormous pressure. The speed with which the current pandemic spread partly illustrates the extent to which this dimension of management failed to take measures to ensure containment, as happened during the initial outbreak in Hubei province. Nor indeed were governments of subsequently affected countries able to contain the imported transmission chains and stop them from spreading across further national boundaries. These imported transmission chains were swiftly converted to local transmission chains and from there went on to spread locally. To be effective in this context, ALE would need to be well-conceptualised and well-designed for this specific audience, in terms of how the training intervention is prepared, the approach adopted when it is presented, reaction speed, and content production, among others. We can now state with sufficient certainty that policymakers' lack of appropriate reaction to COVID-19 was (and in some ways always is) a major contributor to the current disaster, specifically with regard to non-containment factors (Day 2020; Wang et al. 2020; Wintour 2020).

\section{Journalists and other media agents}

Their privileged relationship with the public and the nature of their work place professional journalists and other media agents at the centre of attention, and they are accountable for ensuring that correct information is disseminated to populations. 
Therefore, they must be ALE agents. For this to happen, it is essential that there is prior training in the sense of being mobilised for an emergency so that when issues occur they may have effective social utility. The COVID-19 pandemic has already shown that in some cases the media were responsible for major communication problems and disseminating fake news, which resulted in citizens stockpiling goods that were unrelated to the problem, and caused social confusion, alarmism and other inappropriate behaviour. There is a need for countries to conceptualise the role and functions of these professionals and what ALE content they should promote.

\section{Security personnel}

In many countries it has become necessary to deploy the police or military to assist in ensuring that citizens comply with lockdown regulations. These personnel need to be trained to deal with the fears and apprehensions of the public, to help where needed and to deal appropriately within the law with those who flout country regulations.

\section{Frontline workers}

This category of workers - including refuse removers, distribution/delivery workers and shop assistants - need information at the correct level for their engagement, on how to ensure their own personal safety whilst working under pandemic conditions and how to protect their families when they return to their homes.

\section{Informal sector economy workers}

In many countries, the informal economy makes up the bulk of (self-)employment. In times of crisis and economic downturn, the role of the informal sector becomes more crucial as a form of social assistance and a means of poverty alleviation, particularly in developing countries with inadequate social protection. This is especially so for women and young people, migrants, refugees and displaced people, who may not have access to work in the formal sector or who need to generate an income through informal work. Informal sector workers are especially vulnerable to the impact the COVID-19 or any other pandemic or epidemic because (1) they cannot access the health facilities or social protection benefits available to workers in formal employment; (2) their activities rarely lead to financial security; and (3) the nature of their work is usually dependent on their labour which means that their absence often leads to loss of livelihood. Training peer educators to train this large section of the economy is critical to ensuring they have sufficient knowledge to understand and follow safety protocols.

\section{Educators}

This category includes a broad range of educators, including adult educators, literacy educators, community development workers, community health workers, extension 
officers and peer educators to disseminate carefully designed interventions in all the relevant target languages to ensure that every citizen has access to and understands the knowledge, attitudes, perceptions and behaviour necessary to filter out misinformation and to engage in following the protocols as they evolve with the evolution of the pandemic. With the re-opening of education venues, schools and higher education institutions, this category of personnel needs to be given additional training on how to care for their own safety, classroom and lecture room sanitation and to ensure the safety of learners in their classes and on route to school thus requiring that taxi and bus drivers are adquatly trained in providing services to these communters.

\section{Conclusion}

As we have argued, in the face of the current COVID-19 pandemic, but also in the knowledge that future pandemics and other emergencies are likely to occur in the future, it is vital that ALE is understood as an effective healthcare tool and an element of defence for national and regional populations. To begin with, ALE presents an essential tool to provide literacy, numeracy and digital inclusion. These elements are necessary in order to access the platforms and content that will later be required in an emergency. In effect, ALE must be regarded as a primary tool for political, communicational and social action. Many lives will depend on it, possibly more than those who rely on medicines and hospitals.

Much has already been learned from the current COVID-19 pandemic that supports the contention of the Mid-term Review Conference (held in Suwon, South Korea, in 2017) of the International Conferences on Adult Education (CONFINTEA) ${ }^{14}$ of a need for ALE in situations of national disaster:

Consideration should be given to providing ALE for disaster preparedness, disaster alleviation and recuperation (UIL 2018, p. 8).

This argument was reiterated at a capacity-building workshop held by UNESCO's Institute for Lifelong Learning (Shanghai, October-November 2019). ${ }^{15}$ As the first author points out in the paper he presented during that workshop (Lopes 2019), disaster preparedness and the provision of ALE are critical, and it is necessary to put them into practice.

So far, management of the current COVID-19 pandemic has only drawn on a small fraction of ALE potential as a critical tool to contain the dissemination and

\footnotetext{
14 "In 1949, reflecting on the end of the Second World War, UNESCO Member States met in Elsinore, Denmark, to discuss how adult learning and education (ALE) could help promote world peace and international understanding. That meeting marked the beginning of an enduring and fruitful global dialogue on ALE. It became the first of six International Conferences on Adult Education, known as 'CONFINTEA' (their French acronym: CONFérence INTernationale sur l'Education des Adultes)" (https://uil. unesco.org/adult-education/confintea [accessed 28 May 2020]).

15 The capacity-building workshop was entitled "Developing education systems from a lifelong learning perspective". It was held from 28 October to 8 November 2019 at Shanghai Open University.
} 
generation of new transmission chains. The speed with which the pandemic has spread throughout the world shows that this tool has not yet been used effectively.

There is an urgent need to learn from the mistakes made during the spread of the current pandemic and to change the way that future disasters are managed, incorporating ALE as a critical part of the security measures employed by people and their countries. This is something that will require significant investment; in its absence, countries will need to be prepared to assume the political, human and economic responsibilities of inaction.

Acknowledgments The authors acknowledge Dr Diogo Franco of the scientific secretariat of USP-ICSUCP for his support of this article.

\section{Compliance with ethical standards}

Conflict of interest The authors declare that there is no conflict of interest.

\section{References}

Adams, J. G., \& Walls, R. M. (2020). Supporting the health care workforce during the COVID-19 global pandemic. JAMA, 323(15), 1439-1440. https://doi.org/10.1001/jama.2020.3972.

Aldrich, D. P., \& Meyer, M. A. (2015). Social capital and community resilience. American Behavioral Scientist, 59(2), 254-269. https://doi.org/10.1177/0002764214550299.

Anderson, R. M. (2020). How will country-based mitigation measures influence the course of the COVID19 epidemic? The Lancet, 395(10228), 931-934. https://doi.org/10.1016/S0140-6736(20)30567-5.

Bell, C. (2020). COVID-19 and violent conflict: Responding to predictable unpredictability. Just Security, Art. 69340 [online article, 24 March]. Retrieved 6 April 2020 from https://www.justsecuri ty.org/69340/covid-19-and-violent-conflict-responding-to-predictable-unpredictability/.

Boseley, S. (2020). More than 1,700 health workers infected by coronavirus in China. The Guardian, 14 February. Retrieved 30 March 2020 from https://www.theguardian.com/world/2020/feb/14/morethan-1700-health-workers-infected-by-coronavirus-in-china.

Boulle, A., Bock, P., Osler, M., Cohen, K., Channing, L., Hilderbrand, K., Mothibi, E., Zweigenthal, V., Slingers, N., Cloete, K., \& Abdullah, F. (2008). Antiretroviral therapy and early mortality in South Africa. Bulletin of the World Health Organization, 86(9), 657-739. Retrieved 27 May 2020 from https://www.who.int/bulletin/volumes/86/9/07-045294/en/.

Day, M. (2020). Covid-19: Surge in cases in Italy and South Korea makes pandemic look more likely. British Medical Journal, 368, m751. https://doi.org/10.1136/bmj.m751.

De Sousa Santos, B. (2020). A Cruel Pedagogia do Vírus [The cruel pedagogy of the virus]. Retrieved 14 May 2020 from https://mega.nz/folder/KocEAK4D\#wbKK76PMfpLm9TSWNEBEkA/file/781jS KKC.

Depoux, A., Martin, S., Karafillakis, E., Preet, R., Wilder-Smith, A., \& Larson, H. (2020). The pandemic of social media panic travels faster than the COVID-19 outbreak. Journal of Travel Medicine, taaa031. https://doi.org/10.1093/jtm/taaa031.

Drain, P. (2015). Implications of repealing the Cuban embargo for US medicine and public health. American Journal of Public Health, 105(11), 2210-2211. https://doi.org/10.2105/AJPH.2015.302894.

Economist (2020). Unequal protection: American inequality meets Covid-19. The Economist, 18 April. Retrieved 21 May 2020 from https://www.economist.com/united-states/2020/04/18/american-inequ ality-meets-covid-19.

Greenhalgh, T., Schmid, M. B., Czypionka, T., Bassler, D., \& Gruer, L. (2020). Face masks for the public during the covid-19 crisis. British Medical Journal, 369, m1435. https://doi.org/10.1136/bmj. m1435.

Hageman, J. R. (2020). The coronavirus disease 2019 (COVID-19). Pediatric Annals, 49(3), e99-e100. https://doi.org/10.3928/19382359-20200219-01. 
Handmer, J., Van der Merwe, M., \& O’Neill, S. (2019). The risk of dying in bushfires: A comparative analysis of fatalities and survivors. Progress in Disaster Science, 1, Art. 100015. https://doi. org/10.1016/j.pdisas.2019.100015.

Henley, J. (2020). Coronavirus precautions around Europe. The Guardian, 4 March. Retrieved 30 March 2020 from https://www.theguardian.com/world/2020/mar/04/coronavirus-precautions-around-europ e.

Himmelstein, D.U., \& Woolhandler, S (2016). Public health's falling share of US health spending. American Journal of Public Health, 106(1), (56-57). https://doi.org/10.2105/AJPH.2015.302908.

HRW (Human Rights Watch) (2020) US: Address impact of Covid-19 on poor virus outbreak highlights structural inequalities. Human Rights Watch, 19 March [online article]. Retrieved 21 May 2020 from https://www.hrw.org/news/2020/03/19/us-address-impact-covid-19-poor.

Huang, S. (2020). COVID-19: Why we should all wear masks - there is new scientific rationale. Medium [blogpost 27 March]. Retrieved 4 June 2020 from https://medium.com/@Cancerwarrior/covid -19-why-we-should-all-wear-masks-there-is-new-scientific-rationale-280e08ceee71.

ILO (International Labour Organization) (1993). Resolution concerning statistics of employment in the informal sector adopted by the Fifteenth International Conference of Labour Statisticians (January 1993). Geneva: ILO. Retrieved 27 May 2020 from https://www.ilo.org/wcmsp5/groups/public/dgreports/-stat/documents/normativeinstrument/wcms_087484.pdf.

Jones, D. S. (2020). History in a crisis - lessons for Covid-19. The New England Journal of Medicine, 382, 1681-1683. https://doi.org/10.1056/NEJMp2004361.

Kock, R. A., Karesh, W. B., Veas, F., Velavan, T. P., Simons, D., Mboera, L. E. G., et al. (2020). 2019$\mathrm{nCoV}$ in context: Lessons learned? The Lancet Planetary Health, 4(3), E87-E88. https://doi. org/10.1016/S2542-5196(20)30035-8.

Lancet, The. (2020). Editorial: COVID-19: Too little, too late? The Lancet, 395(10226), 755. https://doi. org/10.1016/S0140-6736(20)30522-5.

Laughland, O. (2020). A perfect storm: Poverty and race add to Covid-19 toll in US deep South. The Guardian, 12 April. Retrieved 21 May 2020 from https://www.theguardian.com/us-news/2020/ apr/12/coronavirus-us-deep-south-poverty-race-perfect-storm.

Legido-Quigley, H., Asgari, N., Teo, Y. Y., Leung, G. M., Oshitani, H., Fukuda, K., et al. (2020). Are high-performing health systems resilient against the COVID-19 pandemic? The Lancet, 395(10227), 848-850. https://doi.org/10.1016/S0140-6736(20)30551-1.

Leung, C. C., Lam, T. H., \& Cheng, K. K. (2020). Mass masking in the COVID-19 pandemic: People need guidance. The Lancet, 395(10228), 945. https://doi.org/10.1016/S0140-6736(20)30520-1.

Lopes, H. (2019). ALE is the key for a healthy world. Paper presented at the capacity-building workshop "Developing education systems from a lifelong learning perspective", held from 28 October to 8 November 2019 at Shanghai Open University in China. https://doi.org/10.13140/RG.2.2.34102 .86084 .

Lopes, H. (2020). Keynote presentation at the 2nd "UNESCO Learning cities respond to COVID-19" webinar, 24 March. https://en.unesco.org/events/webinar-unesco-learning-cities-respond-covid-19.

Lopes, H., \& Middelton, J. (2020). ASPHER Statement on the strategic use of masks, April 2020. Brussels: Association of Schools of Public Health in the European Region (ASPHER). https://doi. org/10.13140/RG.2.2.25528.70403.

Lopes, H., Middelton, J., Martin Moreno, J., Chambaud, L., Davidovich, N., Barros, H., Signorelli, C., \& Woodhead, T. (2020a). Strategic use of masks as an element of a non-pharmaceutical measures set for a pandemic. ASPHER Technical Report, April 2020. Brussels: Association of Schools of Public Health in the European Region (ASPHER). https://doi.org/10.13140/RG.2.2.25214.13125.

Lopes, H., Middleton, J., Guchtenaere, A., \& Franco, D. (2020b). ASPHER statement on the use of masks by children [draft version, May]. Brussels: Association of Schools of Public Health in the European Region (ASPHER). https://doi.org/10.13140/RG.2.2.17790.61762.

Mafuma, N. (2020). Covid-19: Community healthcare workers vital to South Africa's response. The Daily Maverick, 21 April. Retrieved 15 May 2020 from https://www.dailymaverick.co.za/artic le/2020-04-21-covid-19-community-healthcare-workers-vital-to-sas-response/

Mao, F. (2020). Coronavirus panic: Why are people stockpiling toilet paper? BBC News, 4 March [online article]. Retrieved 3 March 2020 from https://www.bbc.com/news/world-australia-51731422.

Marzocchi, A. (2020). Coronavirus, muore sindaco nel Bergamasco. In città è emergenza: "Una sepoltura ogni mezz'ora, sembra una uerra". E il crematorio lavora 24 ore al giorno [Coronavirus, mayor dies in Bergamasco. The city is in a state of emergency: "A funeral every half hour, it seems like a war". And the crematorium works 24 hours a day]. Il Fatto Quotidiano, 14 March. Retrieved 31 March 
2020 from https://www.ilfattoquotidiano.it/2020/03/14/coronavirus-muore-sindaco-nel-bergamasco -in-citta-e-emergenza-una-sepoltura-ogni-mezzora-sembra-una-guerra-e-il-crematorio-lavora-24ore-al-giorno/5736518/.

McKay, V.I. (2018). Literacy, lifelong learning and sustainable development. Australian Journal of Adult Learning, 58(3), 390-425. Retrieved 21 May 2020 from https://files.eric.ed.gov/fulltext/EJ1199862. pdf.

McKay, V.I. (2019). Communities in action: The participation of communities in two South African literacy campaigns. In I. Eloff (Ed.), Handbook of quality of life in African societies. (pp. 23-44). Cham: Springer. https://doi.org/10.1007/978-3-030-15367-0_2.

McKay, V.I. (2020). Learning for development: Learners' perceptions of the impact of the Kha Ri Gude Literacy Campaign. World Development, 125, Art. 104684. https://doi.org/10.1016/j.world dev.2019.104684.

McKay, V., Mokotong, E., \& Sham, B. (2003). Our graves are open: Report on the prevention of HIV/ Aids in the informal sector in South Africa. Compiled on behalf of the International Labour Organisation. Pretoria: International Labour Organisation. Retrieved 15 May 2020 from https://www.resea rchgate.net/publication/335402316_Our_graves_are_open_Report_on_the_prevention_of_HIVAi ds_in_the_informal_sector_in_South_Africa_Compiled_on_behalf_of_the_International_Labou r_Organisation.

McKay, V., \& Romm, N. (2007). A systemic approach to addressing HIV/AIDS in the informal economy in Zambia: Methodological pluralism revisited. International Journal of Applied Systemic Studies, 1(4), 375-397. https://doi.org/10.1504/IJASS.2007.019302.

McKay, V., \& Romm, N. (2008). Active research towards the addressal of HIV/AIDS in the informal economy in Zambia: Involvements in social development. Action Research, 6(2), 149-170. https:// doi.org/10.1177/1476750307087050.

Middleton, J., Martin-Moreno, J. M., Barros, H., et al. (2020). ASPHER statement on the novel coronavirus disease (COVID-19) outbreak emergency. International Journal of Public Health, 65(3), 237-238. https://doi.org/10.1007/s00038-020-01362-x.

Nakkazi, E. (2019). South Africa reports successful third-line HIV treatment programme. NamAIDSmap [webnews 4 January]. Retrieved 3 June 2020 from http://www.aidsmap.com/news/jan-2019/south -africa-reports-successful-third-line-hiv-treatment-programme 4 January 2019.

Nutbeam, D. (2000). Health literacy as a public health goal: A challenge for contemporary health education and communication strategies in the 21st century. Health Promotion International, 15(3), 259-267. https://doi.org/10.1093/heapro/15.3.259.

Nutbeam, D. (2015). Defining, measuring and improving health literacy. Health Evaluation and Promotion, 42(4), 450-456. https://doi.org/10.7143/jhep.42.450.

OECD (Organisation for Economic Co-operation and Development) (2020). OECD interim economic assessment. Coronavirus: The world economy at risk. Interim Report March 2020. OECD Economic Outlook, 2019 (Supplement 2). https://doi.org/10.1787/7969896b-en.

Osman, A., Ladhani, S., Findlater, E. \& McKay, V.I. (2017). Curriculum framework for the sustainable development goals. London: Commonwealth Secretariat. Retrieved 21 May 2020 from https://www. thecommonwealth-educationhub.net/wp-content/uploads/2017/01/Curriculum_Framework_for_ SDGs_July_2017.pdf.

OUP (Oxford University Press) (n.d.). Vector. In Lexico.com [online dictionary]. Detroit, MI: Lexico. com. Retrieved 25 May 2020 from https://www.lexico.com/definition/vector.

Porta, M. (Ed.). (2014). A dictionary of epidemiology (6th ed.). New York: Oxford University Press.

Remuzzi, A., \& Remuzzi, G. (2020). COVID-19 and Italy: What next ? The Lancet, 395, 1125-1128. https://doi.org/10.1016/S0140-6736(20)30627-9.

Thompson, E. E. (2019). Communicating a health risk/crisis: Exploring the experiences of journalists covering a proximate pandemic. Science Communication, 41(6), 707-731. https://doi. org/10.1177/1075547019878875.

UIL (UNESCO Institute for Lifelong Learning) (2009). Global report on adult learning and education. Hamburg: UNESCO Institute for Lifelong learning. Retrieved 31 March 2020 from https://unesd oc.unesco.org/ark:/48223/pf0000186431.

UIL (2012). UNESCO Guidelines for the recognition, validation and accreditation of the outcomes of non-formal and informal learning. UIL/2012/PI/H/3rev2. Hamburg: UNESCO Institute for Lifelong Learning, Hamburg. Retrieved 24 May2020 from https://unesdoc.unesco.org/ark:/48223/pf000 0216360 , 
UN (United Nations) (2015). Transforming our world: The 2030 Agenda for sustainable development. A/RES/70/1. New York: UN. Retrieved 24 May 2020 from https://sustainabledevelopment.un.org/ post2015/transformingourworld/publication.

UIL (2017). Literacy and numeracy from a lifelong learning perspective. UIL Policy Brief 7. Hamburg: UNESCO Institute for Lifelong learning. Retrieved 31 March 2020 from https://unesdoc.unesco.org/ ark:/48223/pf0000247094.

UIL (2018). The power of adult learning and education; A vision towards 2030. Suwon-Osan CONFINTEA VI Mid-Term Review Statement: Hamburg: UNESCO Institute for Lifelong Learning. Retrieved 28 May 2020 from https://unesdoc.unesco.org/ark:/48223/pf0000261223.

UIL (2020). Adult education and the challenge of exclusion. UIL Policy Brief 10. Hamburg: UNESCO Institute for Lifelong learning. Retrieved 27 May2020 from https://unesdoc.unesco.org/ark:/48223/ pf0000372904.

Vandemoortele, J., \& Delamonica, E. (2000) The "education vaccine" against HIV. Current Issues in Comparative Education, 3(1), [online article]. Retrieved 31 March 2020 from https://www.tc.colum bia.edu/cice/pdf/25676_3_1_Vandemoortele_Delamonica.pdf.

Vargas, J. G. (Ed.). (2020). Emergencias pandémicas en un mundo globalizado: amenazas a la seguridad [Pandemic emergencies in a globalized world: security threats] Colección uadernos de Estragegia (series) (Vol. 203). Madrid: Instituto Español de Estudios Estratégicos (IEEE).

Wang, H., Wang, Z., Dong, Y., Chang, R., Xu, C., Yu, X., Zhang, S., Tsamlag, L., Shang, M., Huang, J., Wang, Y., Xu, G., Shen, T., Zhang, X., \& Cai. Y. (2020). Phase-adjusted estimation of the number of Coronavirus disease 2019 cases in Wuhan, China. Cell Discovery 6, Art. 10. https://doi. org/10.1038/s41421-020-0148-0.

WHO (World Health Organization) (n.d.). Ebola virus disease [dedicated webpages]. Geneva: World Health Organization. Retrieved 27 May 2020 from https://www.who.int/health-topics/ebola $\#$ tab=tab_1.

WHO (2007). Questions and answers on avian influenza in relation to animals, food and water. Geneva: World Health Organization. Retrieved 26 May 2020 from https://www.who.int/foodsafety/areas _work/zoonose/avian/en/index1.html.

WHO (2016). World health statistics 2016: Monitoring health for the SDGs. Geneva: World Health Organization. Retrieved 7 April 2020 from https://www.who.int/gho/publications/world_health_ statistics/2016/en/.

WHO (2018). Zika virus [dedicated webpage]. Geneva: World Health Organization. Retrieved 27 May 2020 from https://www.who.int/news-room/fact-sheets/detail/zika-virus.

WHO (2020a). Mental health and psychosocial considerations during COVID-19 outbreak. WHO/2019nCoV/MentalHealth/2020 [12 March, online advice document]. Geneva: World Health Organization. Retrieved 30 March 2020 from https://www.who.int/docs/default-source/coronaviruse/menta 1-health-considerations.pdf?sfvrsn=6d3578af_8.

WHO (2020b). Report of the WHO-China joint mission on coronavirus disease 2019 (COVID-19). Geneva: World Health Organization. Retrieved 30 March 2020 from https://www.who.int/docs/ default-source/coronaviruse/who-china-joint-mission-on-covid-19-final-report.pdf.

WHO (2020c). Global Health Expenditure Database [online resource]. Geneva: World Health Organizazion. Retrieved 24 May 2020 from https://apps.who.int/nha/database.

WHO (2020d). Dengue and severe dengue [dedicated webpage]. Geneva: World Health Organization. Retrieved 27 May 2020 from https://www.who.int/news-room/fact-sheets/detail/dengue-and-sever e-dengue.

WHO (2020e). WHO Director-General's Statement on IHR Emergency Committee on Ebola Virus Disease in the Democratic Republic of the Congo [webnews item, 14 April]. Geneva: World Health Organization. Retrieved 27 May 2020 from https://www.who.int/news-room/detail/14-04-2020who-director-general-s-statement-on-ihr-emergency-committee-on-ebola-virus-disease-in-thedemocratic-republic-of-the-congo.

Wintour, P. (2020). "An absolute disaster": Iran struggles as coronavirus spreads. The Guardian, 3 March. Retrieved 30 March 2020 from https://www.theguardian.com/world/2020/mar/03/an-absolute-disas ter-iran-struggles-as-coronavirus-spreads.

Wu, Z., \& McGoogan, J. M. (2020). Characteristics of and important lessons from the coronavirus disease 2019 (COVID-19) outbreak in China: Summary of a report of 72314 cases from the Chinese Center for Disease Control and Prevention. JAMA, 323(13), 1239-1242. https://doi.org/10.1001/ jama.2020.2648. 
Yee, J., Unger, L., Zadravecz, F., Cariello, P., Seibert, A., Johnson, M. A., et al. (2020). Novel coronavirus 2019 (COVID-19): Emergence and implications for emergency care. Journal of the American College of Emergency Physicians Open, 2020(1), 63-69. https://doi.org/10.1002/emp2.12034.

Publisher's Note Springer Nature remains neutral with regard to jurisdictional claims in published maps and institutional affiliations.

Henrique Lopes is Professor of Public Health and scientific coordinator of research projects at the Public Health Unit of the Institute of Health Sciences of the Catholic University of Portugal. His main research areas are: Public Health Policies, Health Education, Participation of patients in decision making in health, Epidemiology and viral epidemiological modelling, Health Quality. In addition, he has been President of the Portuguese Sectorial Commission for Quality in Health since 2012. He is former president of an international scientific society linked to Gambling Addiction. He is a current member of the European COVID Task Force of the Association of Public Health Schools in the European Region (ASPHER).

Veronica McKay is currently Acting Vice Principal: Teaching and Learning at the University of South Africa (UNISA). She was previously the Dean of the College of Education, University of South Africa (UNISA), where she was responsible for the implementation of programmes for initial and continuous development of teachers, from preschool to post-schooling, including adult and community education and training. Her research areas include non-formal education and adult learning, literacy and language education, gender and social development. She was previously seconded from the university to the South African Department of Basic Education, where she was appointed Chief Executive Officer of the South African Literacy Campaign.

\section{Affiliations}

\section{Henrique Lopes ${ }^{1}\left[\right.$ ] Veronica McKay ${ }^{2}$}

Henrique Lopes

henrique.lopes@ucp.pt

1 Public Health Unit of the Institute of Health Sciences, Universidade Católica Portuguesa (Catholic University of Portugal), Palma de Cima, Lisbon, Portugal

2 College of Education, University of South Africa, Pretoria, South Africa 